Journal of Social Sciences 8 (2): 149-162, 2012

ISSN 1549-3652

(C) 2012 Science Publications

\title{
Scientific Legitimation of the European Union's Competence Development Policy
}

\author{
Rosario Sergio Maniscalco \\ Department of Education, \\ Faculty of Education, University of Turku, 20014, Finland
}

\begin{abstract}
This study provides an accessible account of the policy making process of the European Union in the arena of adult skills and competence development. In particular, the way skill standards for adult learners is designed in the EU official statements is investigated, analyzing the developments in the European Union's adult education policies since the Lisbon process was launched in order to verify to what extent they are evidence-based and legitimated through scientific research and specific ex-ante studies. In fact, because of the ageing work force in Europe, but also in the light of the recent economic downturns and the increased labor market's flexibility and dynamics, many governments have tried to foster the involvement and participation of adults in lifelong learning paths for them to suit the transformations of the knowledge-based societies and be active and competitive even in older ages. This empirical paper is based on literature review and content analysis of the relevant policy documents and official EU statements. The main findings show how, beyond declared purposes and political slogans, the way the EU is shaping the adult learners' upskilling significantly appears to aim at the substantial bolstering of basic and digital skills in order to cope with the knowledge economy rather than giving emphasis to more comprehensive sets of competences for lifelong learning and active ageing, which are going to be needed more than ever in the years to come.
\end{abstract}

Key words: European educational policies, Adult Education (AE), competence development, Action Plan for Adult Learning (APAL)

\section{INTRODUCTION}

At the beginning of the seventies, in a lucid popular booklet, Nobel prize Lorenz (1973) qualified the disproportionate growth of the human species as one of the eight "civilized man's deadly sins". If the 20th century has been the century of the great demographic expansion, especially for the Western countries, the 21 st century will be the century of the aging of the population. Policy analysts, sociologists, politicians and economists currently agree on the difficulties that modern societies will face in this regard. The first cause of the aging population is the significant decrease in the fertility rates, combined with important progresses made in the medical and biological sciences. Secondly and consequently, the increase in life expectancy and the control of early deaths and 'unplanned' births play a role. Moreover, a number of relevant changes in human behaviors, cultural dynamics and lifestyles, including for example the different status of the female population, new marriage and family models, mobility and migrations are contributing factors (Mazza and Capacci, 2006).

Getting old is indeed a privilege and an ultimate goal for society, but also represents a challenge to large segments of the socio-economic systems. On an individual level, aging can be considered as evidence of the favorable condition the human species has reached. Medical progress has made people live longer, with better a quality of life, better hygienic conditions, a richer and better balanced diet and improved psycho-physical well-being. Not only does medical and pharmaceutical progress in treating illness and disease improve the health conditions of older people, new therapies aiming at modifying the process of ageing itself have also been recently developed in order to further extend the life duration (Franceschi et al., 2004).

As good as these prospects are for the individual, looked from a governance perspective, the outlook is radically different: the increase of the population over 45 and especially 65 has been accompanied, in the last decades, by a decrease of the population aged between 25 and 45 , a worrying turnaround of the generation ratio which has produced unbalance in the organizational structure of many societies (EC, 2009a). The health care and welfare systems will come up against growing difficulties because of the different and expanded financial needs consequent to the increase in health assistance the populations of most developed 


\section{J. Social Sci., 8 (2): 149-162, 2012}

countries will require. But the biggest challenges related to the ageing population hinge upon, most of all, the dynamics of this phenomenon, the rapidity and intensity of its impact (Maniscalco, 2010b). Unless there will be contrary and presently unpredictable developments, there is an urgency to understand the transformations taking place, so that political choices will be based on collectively shared and balanced actions to face these challenges.

According to some recent reports by the OECD (2003, 2006a) and Eurostat EC, 2009 on the demography of the Western countries, the percentage of the population that is 65 years or older is rising in all the OECD and EU Member States (hereafter MS) and is expected to continue doing so. The number of inactive elderly as a ratio of the numbers in the total labor force is also increasing. All European countries will experience a sharp increase in the dependency ratio over the period 2020-2050, projected to more than double from its current level. The European Commission (EC, 2010) has recently estimated that over the next 30 years the number of younger Europeans (up to 24 years) will fall by $15 \%$, while the median age is projected to rise from 40.4 years to 47.9 years in 2060 .

If workers will need to stay longer in the labor market, the metamorphosis that societies and global economies are experiencing especially since the last decade cannot but be also taken into account. The above mentioned increased dynamics of the markets, the job flexibility imposed on the workforce, the higher levels of qualifications required, the competitiveness for productivity are all elements urging governments to get equipped with new and more adequate systems of continuing education and training in order to cope with these transformations and adapt to the knowledge-based society. The prosperity that Europe will attain in the next decades will certainly be the result of a competition among the most developed economies (United States, European Union, Japan) and the fastest developing ones (China, India). The effects of this competition will depend largely on the quantity but also the quality of the human capital each of these economies will be able to deploy.

The use of the term 'human capital' in the modern (neoclassical economic) academic literature dates back to the pioneering work of Theodore Schultz, (1961) and especially Becker (1964) book entitled Human Capital. Schultz identified human capital with the investment in education arguing that increases in national and per capita income are a consequence of additions to the 'stock' of education. Becker broadened the concept of the investment in human capital (not only via education, but also through on-the-job training and other investments to improve the worker's productivity, emotional and physical health) and the outputs are claimed to partly depend on the rate of return on the human capital owned. Thus, 'human capital' was defined as a means of production, for which additional investment yields additional output: "The knowledge and skills a worker has-which come from education and training, including the training that experience brings generate a certain stock of productive capital" (Baron and Armstrong, 2007).

Nowadays, human capital is defined as "the knowledge, skills, abilities and capacity to develop and innovate possessed by people in an organization (Baron and Armstrong (2007). See also O'Sullivan and Sheffrin (2003) and a growing number of theoretical and empirical studies focus on the relation between human capital and economic growth. Some theorists have also proposed a selective application to the link between human capital accumulation (often associated with increasing levels of education) and long-run economic growth, even if "despite the elegant appeal of this proposition, theoretical and empirical verification has been difficult to establish" (Savvides and Stengos, 2009).

Often considered as an element of the evolution of capitalism, knowledge has become central in 'modern' contemporary societies, historically entering therefore a new era intimately related to the development of information technology, globalization and new network structures (Bell, 1973; Castells, 1996; Drucker, 2009). Thus, while Barro and Lazear (2002) reinforced his already optimistic vision of human capital picturing a society where investments in workers' skills and lifelong learning in general would generate unprecedented prosperity and social equality, Nico Stehr (1994) introduced the definition of knowledge societies as a specific model of societies whose characteristic is that knowledge forms a major component of any human activity. In a knowledge society, knowledge becomes a major creative force. With current technologies, in fact, knowledge societies are not constrained by geographic proximity: they offer many more possibilities for sharing, archiving and retrieving knowledge. Finally, pushing beyond human capital theory, knowledge is the most important capital form of in the present age and hence the success of any society lies in investing in and using it in the most profitable way.

As the continuing development of a 'knowledge economy' is supposed to be driven by innovation (Atkinson and Court, 1998), the theoretical developments, from neoclassic economic growth theories to the new growth theories and various extensions, are increasingly paying academic attention to the roles of knowledge and entrepreneurship. If, in economic growth analysis, in fact, educational attainment has gained a central role (Barro, 1999; Barro, 2001), knowledge capital has been measured in 


\section{J. Social Sci., 8 (2): 149-162, 2012}

most cases by research and development ( $\mathrm{R}$ and $\mathrm{D})$ indices or by college and graduate educational attainment, which often serves as an epicenter of innovation and $\mathrm{R}$ andD. Efforts to use graduate education attainment as a measure of knowledge capital remain however limited.

Considering the investments in education for the workforce, statistics render a sobering picture: in the EU-27 the average levels of participation to lifelong learning by adults are rather modest $(9.7 \%$ in 2007 and now even decreasing to $9.5 \%$ in 2010) (The objective fixed by the EU within the Lisbon process was to reach a participation rate of adult learners to lifelong learning of $12.5 \%$ by 2010 . See EC (2008a) and EC (2010) while $40.4 \%$ of the adults between 55 and 64 years old have not reached a level of post-secondary education and for the people over 65 the average rate reaches $62 \%$ (EC, 2010). The aging population will certainly need to be accompanied by a new attitude of the policy makers in order to stimulate the involvement of the 'older adults' in continuing education and training paths, aiming at stimulating not only the quality of work and the productivity of the system, but also opportunities for the workforce to adapt skills and competences to the new markets' needs and obtaining new qualifications and higher levels of education that can help older workers to keep being competitive and express a full and active citizenship.

Longitudinal background: In 2000, when the EU launched the Lisbon agenda, the challenge was to stimulate innovation as a major route to reaching the goal of becoming the most dynamic and competitive knowledge-based economy in the world (EU, 2000). In May 5, 2003 the Council of the European Ministers of Education approved 5 Reference Levels of the European Performance (better known as "benchmarks") and a set of 29 indicators to monitor the effectiveness of the Lisbon strategy, a result of the political agreement based on a series of "adjustments" of the "second best" principle. The principle of the "second best" refers to what is the optimal policy when the true optimum (the first best) is unavailable due to constraints on policy choice. See Lipsey and Lancaster (1956) Since, the EC performed a detailed examination of the progress towards the 'Lisbon objectives' on a yearly basis. Comparative benchmarking has been identified by the OECD as the "basis for improvement", claiming that "it is only through such benchmarking that countries can understand relative strengths and weaknesses of their education systems and identify best practices and ways forward" (OECD, 2006b) and the participation to international testing and assessment often appeared to be linked to efforts to reform educational systems at national level (Baker and LeTendre, 2005).

Already three years after the official start, in 2003, the Commission declared that "the reform undertaken are not up to the challenges and their current pace will not enable the Union to attain the objectives set" (EC, 2003). Also the reports of the following two years came to similar conclusions (EC, 2004; 2005). In 2006, a study by the Centre for Economic Performance at the London School of Economics (LSE, 2006) confirmed that progress had been poor: the United States had significantly higher productivity than the European average; US GDP per hour was over $15 \%$ higher than Europe's; and US GDP per capita was over 30\% higher. From the end of the Second World War until the mid1990s, "Europe was catching up with US levels of productivity" but, since then, US productivity growth had been faster than in Europe (ibid, 1). Not to mention the rapidly raising economies of India and especially China. Another scientific paper published the very same year (Ertl, 2006), documented:

The slow progress regarding the Lisbon goals for education and training seems to indicate [...] that the impact of EU programmes and projects for educational provision in the Member States remains limited.

In particular, the EU set the 'Lisbon target' of increasing research and development to $3 \%$ of GDP by 2010; although the numerical target for R and D seems to make little economic sense, it has been shown how the emphasis on innovation as a route to growth is relevant. Now, the cost of patenting in Europe was esteemed to be, in 2006, about five times the cost of patenting in the United States, while the brain drain from the EU to the United States-as a consequence of better research opportunities and higher wages-was still "a significant phenomenon" (LSE, 2006). Intelligibly, the Lisbon agenda's aim of reversing this trend by the fixed deadline had not materialized.

Another target set in the framework of the Lisbon process was to foster the participation of adults, principal actors of this 'economic challenge', into lifelong learning. According to the 5th benchmark, adult learners continuing education were supposed to reach the rate of $12.5 \%$ by 2010 . The data gathered by the EC in order to monitor the progress towards the Lisbon objectives in 2006 acknowledged that the participation rate was still under $10 \%$ and would "hardly increase significantly" in the following four years (EC, 2008a). Starting from $7.1 \%$ in 2000 , it rose up to $9.6 \%$ in 2006 , but then the growth slowed down and, in 2007, the percentage was still $9.7 \%$ (EC, 2008a). 


\section{J. Social Sci., 8 (2): 149-162, 2012}

A political debate on the fixed targets and benchmarks then occurred between the EU and the MS in order to establish whether they were realistic and, if so, what kind of difficulties the national governments encountered in implementing the European education policies. Several proposals of adjustments to be made in the EU policy for $\mathrm{E}$ andT and Lifelong Learning followed the reflection on the excessive ambitions of the Lisbon goals see EC (2008a): "Progress towards meeting the five benchmarks set for 2010 has been insufficient" (p. 13) and "most of the benchmarks that the Council set for 2010 will not be reached" (p. 3). One of these was "a new wave of EU initiatives in the field, sometimes updating or recycling activities that had not been successful in the past" (Ertl, 2006), such as working groups (often supported by "focus groups" composed by non-governmental experts), Peer Learning Activities (PLAs), regional meetings organized with a direct involvement of the country representatives, intergovernmental agreements and strengthen of thematic networking.

2006 can unmistakably be considered a reference point, as the European Commission called on the MS to promote Adult Education (AE) and to place it firmly on their political agendas by adopting the October 2006 Communication It is never too late to learn (EC, 2006), setting out the general approach to needs and developments in the adult learning sector and through the September 2007 Communication It is always good time to learn (EC, 2007b), launching the Action Plan for Adult Learning (APAL). The Action Plan was intended to help removing the barriers that prevent adults from engaging in learning activities and to improve the quality and efficiency of the adult learning sector. Both Communications were afterwards reinforced by the 2008 Conclusions of the Council on Adult Learning (EU, 2008). The same year, in the sector of the AE, the European Commission decided to establish a Working Group on the implementation of the Action Plan on Adult Learning in order to provide and support the Commission's services with policy advice and assistance and with the clear mandate towards attaining the objectives set out in the work programmer.

The activities of the working group were to be guided by the actions established in the APAL itself and by the actions proposed in the Council Conclusions and the Resolution of the European Parliament and supported by the secretariat of the group and five Focus Groups, centered around the five key actions contained in the Action Plan (Maniscalco, 2010a):

- Analyze effects of reforms in other educational sectors on adult learning;

- Improve the quality of provision
- Increase the possibilities to achieve at least one higher-level qualification ("one step up" principle)

- Speed up the process of assessing and recognizing non-formal and informal learning for disadvantaged groups

- Improve the monitoring of the adult learning sector

On the other hand, studies showing that the labor market was becoming more and more demanding for the workers in terms of increased labor market's flexibility, dynamics and high-qualification job rate (EC, 2007a), but also in the perspective of "anticipating and matching labour market and skills needs", the Council of the EU adopted a Resolution focusing on the New Skills for the New Jobs (EU, 2007), in order to better attain a better balance between the workers' skills and competences and the needs of the modern economy. This way, the EU launched a parallel "political stream" whose target were also, indeed, adults.

To summarize, the main elements that have determined specific education policies for adult learners by the EU are, first of all, the demographic challenge of the European ageing population, but also the role played by socioeconomic theories such as human capital and knowledge societies. The first theory influenced substantially the launch of the European Commission's Action Plan for Adult Learning, the second is the background for the EU Key Competences for Lifelong Learning Recommendation (EU, 2006b) and the New Skills for New Jobs policy statements (EU, 2007; EC, 2008b; EC, 2008c).

In the "Overview of the Adult Skill's issue on the European Agenda" (EC, 2010), the European Commission underlined that:

The concept of lifelong learning within a knowledge-based society, resulting from various societal changes which have progressively emerged in the EU has reinforced this necessity [for AE]. Significantly, the need to support the adult population in developing and updating individual competences throughout their lives is clearly emphasized in several policy documents at the EU level. The Recommendation of the European Parliament and the Council on "Key Competences for Lifelong Learning" and the Council Conclusions on the Action Plan on Adult Learning "It is always a good time to learn" constitute the main reference tools to support policy makers, education and training providers, employers and learners in the Member States to help education and training systems ensure the development of these competences. 


\section{J. Social Sci., 8 (2): 149-162, 2012}

If the EC claimed that "the importance of these competences is clearly stated in the Action Plan on Adult Learning", it nevertheless admitted that "though interdependent, the emphasis is primarily laid on the development and mastering of literacy and numeracy usually qualified as basic skills" (ibid, 27). The deliberations made in relation with the influence of human capital and other HR and organizational theories on lifelong learning and $\mathrm{AE}$ are particularly enlightening when applied to the skills and competences for lifelong and adult learning, often considered as "biographical competencies which individuals require in order to manage their learning careers and participation in lifelong learning" (Hake, 1999).

\section{MATERIALS AND METHODS}

I argue that, in the same way the EU defines adult learner as "25-64 years old persons of working age" (EC, 2010), adult skills are typically linked - also in the European Commission's exercises and policy documents, as it will soon be shown - to the professional environments and correlated to work skills. The question I am discussing in the next paragraph tries to find out, by means of content analysis and through critical review of the relevant literature, whether and to what extent the EU is shaping the adult learners' upskilling giving more emphasis to basic/hard skills in order to train people to cope with the global economy rather than taking into account core/soft skills for its citizens in the scope of binding economic cohesion with social cohesion, one pillar of the EU political mainstreaming together with employment and economic growth (Adnett, 2001), as exemplified by Title XIV of the Maastricht Treaty.

Rationale and analysis: Nowadays, the ability to communicate, influence people, motivate and delegate, to work in teams and deal with differences, multiculturalism and diversity is needed more than ever and also expresses a proactive citizenship (Maniscalco, 2008). According to Murnane and Levy (1996), "in today's competitive economy [...] firms search for applicants with the New Basic Skills, the mix of hard and soft skills that all high-wage employers now require". Also the Organisation for Economic Co-Operation and Development (OECD) refers to Autor et al. (2003) when arguing that the "technological change (in particular computerization) has made problem solving and complex communication skills much more important in the labour market" OECD, 2009.

In 1955, the Harvard Business Review published an article by Katz (1955) entitled Skills of an effective administrator. This article, as Peterson and Fleet (2004) point out, is nowadays considered a classic work on managerial skills "Examining principles of management textbooks can demonstrate another example of Katz's profound impact on the management field. A total of 15 principles books published in the mid-1980s and another 15 textbooks published more recently were examined (some are actually more recent editions of the earlier texts). [...] Textbooks and their authors seem to come and go. However, Katz seems to remain. Over this 20 -year period, ten of the 15 books have gone out of print and been replaced by new books and new authors. However, Katz still appears in $80 \%$ of the books. When Katz is not mentioned, the importance of managerial skills is still discussed but in a more generic manner. Katz's work was specifically referenced by almost all of the early works and by most of the more recent books" (Peterson and Fleet, 2004). Katz argued that an executive's traits or personality characteristics are not important, but what the executive can accomplish. More specifically, he said that it is a set of core skills, which are employed by managers in pursuit of organizational objectives, that is important. According to him, what a manager can accomplish is based on the skills that the he/she possesses, where skill is defined the "ability either to perform some specific behavioral task or the ability to perform some specific cognitive process that is functionally related to some particular task" (ibid). In his thesis a skill is conceived as comprising three components:

- The existence of a domain-specific knowledge base

- A method for accessing this knowledge base; and

- The ability to enact a set of behaviors or cognitions using the retrieved knowledge to perform the given task

The disambiguation of the terminology is not straightforward, though. Mulder et al. (2007) analyze "the lack of a coherent definition of the concept of competence, the lack of a one-to-one relationship between competence and performance, the misled notion that employing the concept of competence decreases the value of knowledge, the difficulties of designing competence-based educational principles at the curriculum and instruction levels, the underestimation of the organizational consequences of competence-based education and the many problems in the field of competence assessment" in most European countries. In their research Knowledge, skills, competence: European Divergences in Vocational Education and Training (VET), Brockmann et al. (2008) also observe:

The analysis reveals the distinct understandings and meanings of outwardly 


\section{J. Social Sci., 8 (2): 149-162, 2012}

similar terms. These meanings are deeply rooted in the countries' institutional structures and labour processes and still inform national debates and policies today. [...] There is a need to develop transnational categories that take into account the social construction of terms such as 'skills' and 'qualifications'.

CEDEFOP 2000 (an agency of the EU for VET), proposed a first comprehensive terminological set of definitions which was intended to take more into account managerial-organizational and educational research developments. The following glossary-table (Descy and Tessaring, 2001) is certainly an important attempt to conceptualize terms such as skill and competence, but still containing ambiguities and crossdefinitions (skills defined as knowledge or experience, competence as capacity to use "know-how, skills, qualifications or knowledge") and still borrowing a big deal from the corporate sector:

- Skill: the relevant knowledge and experience needed to perform a specific task or job and/or the product of education, training and experience which, together with relevant know-how, is characteristic of technical knowledge

- Competence: the proven and individual capacity to use know-how, skills, qualifications or knowledge in order to meet both familiar and evolving occupational situations and requirements

- Generic skills: the skills that support lifelong learning, including not only literacy and numeracy (i.e., basic skills), but also communication skills, problem-solving skills, team-working skills, decision-making skills, creative thinking, computer skills and continuous learning skills

- Transferable competences: the competences individuals have which are also relevant to jobs and occupations others than the ones they currently have or have recently had

- Key/core competences: the sets of skills which are complementary to basic and generic skills and which enable individuals to acquire new qualifications more easily, to adapt to changing technological or organizational contexts and/or to achieve mobility on the labour market, including by means of career development

In another study that CEDEFOP assigned by call for tender to the Groupe ESC Toulouse of the Centre for European Research on Employment and Human Resources (CEDEFOP, 2006a; 2006b), a wide scientific review on the issue further enlarged the previous formulations and even a new theoretical 'prototype' was introduced in order to solve the incoherence and fragmentation of the existing terminology, called
"Unified typology of Knowledge, Skills and Competence". Indeed keeping an eye on the mandate of bridging the academic research and the HR literature with the last EU policy documents on competence, skills, qualifications and recognition/validation of previous learning First of all the European Credit Transfer System (ECTS), then the more recent European Credit Transfer System for VET (ECVET) and the European Qualification Framework (EQF), it well reflects the main trends in the scientific studies on Knowledge, Skills and Attitudes (KSA) which are more and more often using holistic approaches to the definition of competence (Gonczi, 1994; Tovey, 1993; Engle et al., 2001; Hager, 1994), aiming at "combining knowledge, skills and attitudes" (CEDEFOP, 2006b).

The "decision to retain "knowledge, skills and competences' (KSCs) as a unified statement" did not mean, for the researchers of the ESC Group, to simplify as a result of the incorporation of the "metacompetences within the social competences category". They explained: "the problem with using the term $\mathrm{KSCs}$ is that without further qualification, the term competence alone is too broad. [...] Using the term competence as a short-hand for social competence is potentially problematic because the term is most commonly used as a general term for demonstrating requisite knowledge and skills as well as appropriate behaviour in a work context. We therefore strongly recommend that in the interests of analytical precision, ECVET adopts the terminology of cognitive competence, functional competence and social competence" (ibid).

The above mentioned research had been "launched by the European Commission and CEDEFOP to support the work of the Copenhagen Process' technical working group" (CEDEFOP, 2006b) and carried out under the umbrella of the EU quest for scientific legitimacy to feed the educational policy making process with theoretical, conceptual and empirical grounds. Despite such 'quality products' within the EU satellite agencies' cosmos, the reference document in Europe for the orientation and definition of the national skills and competences-based learning curricula, established in 2006 as well by the European Commission through a Recommendation on the Key Competences for lifelong learning (EU, 2006b) The Reference Framework sets out eight key competences: Communication in the mother tongue; Communication in foreign languages; Mathematical competence and basic competences in science and technology; Digital competence; Learning to learn; Social and civic competences; Sense of initiative and entrepreneurship and Cultural awareness and expression, was then criticized two years later by the very same agency of the EU who was in charge to provide legitimation to 
that process. Hence, CEDEFOP (2008a) stresses on the fact that the 'key competences' are a mixture of "cognitive competences" (providing the example of mathematics), "cross-curricular" competences (e.g., learning to learn, social and civic competences) and "underpinning transversal competences" (e.g., critical thinking, creativity, initiative, problem-solving, decision taking and constructive management of feelings) and finally categorizes them as only partially based "on a theoretical or research formulation", otherwise "based on negotiation between stakeholders" (namely the Member States), either just "borrowed/adapted from elsewhere" (e.g., the 20022005 OECD's De.Se.Co. project for the "Definition and Selection of Competencies" (OECD, 2005), probably the best scientific-based project on competences thus far, released one year before and addressing specifically the education policy-makers).

In 2009, as a result of a new call by the EC Directorate General for Education and Culture, another survey for the assessment of the Key Competences EU policy statement was published. The Centre for Social and Economic Research of Warsaw, who carried out the study, reported (CASE, 2009):

The Recommendation of the European Parliament and of the Council on Key competences for lifelong learning defines key competences as comprising knowledge, skills and attitudes. The policies of most EU Member States refer explicitly, or at least implicitly, to knowledge, skills and attitudes in their curriculum frameworks. However, whilst the stated aims of assessments may refer to competence, in practice assessed learning outcomes less frequently include attitudes than knowledge and skills.

In the Recommendation, in fact, competences are defined as "a combination of knowledge, skills and attitudes appropriate to the context" (EU, 2006b), basically endorsing the 2005 theoretical proposal of the ESC Group but simplifying it and dispersing its theoretical formulation's articulation and complexity, thus distancing from the rigorous scientific 'evidence raising' previously undertaken in the legitimation phase.

In educational systems ruled by "binary logic" (Sloan, 2006) where knowledge is true or false and increasingly comes to be identified as what is expressed or described by language (Gustafsson, 2002), where learning outcomes are right or wrong and where the 'objective' tests of the OECD measuring standardized knowledge have the power to orientate the political decisions of the Western countries' education systems (Kamens and McNeely, 2010), where only a limited portion of the human's intelligence range is then valorized, 'transversal' and soft skills are rarely taken into the account in the national curricula. They are left out simply because they are not suitable learning outcomes for an objective, standardized assessment, especially if they are not inscribed in a clear, intelligible and well structured scientific framework (Sekerak and Sveda, 2008). In its survey on the Key Competencies published in 2002, even Eurydice (also an EC network, linked to the D.G. EAC) noticed: "it is only possible to testify to an individual's potential to develop these competencies. Faced with such difficulties, exams tend to concentrate on the testing of knowledge as a much easier measure of what pupils have achieved" (Eurydice, 2002).

A comparison with other competence frameworks of reference discloses that the lack of operational paradigmatic ramification of the 2006 statement on the Key Competences could be another obstacle the EU countries have to face in implementing it (CASE, 2009):

For example, the EQF refers to knowledge, skills and competences across eight levels, while the key competences for lifelong learning refer to knowledge, skills and attitudes and are not identified at different levels; the Council of Europe language framework is competence-based, widely used and contains at present six levels.

The modest implementation of the European policies on adult skills and AE in general also seem to be connected to the fact that education, being one critical area of the nation states' sovereignty, does not fall within the exclusive competence of the EU and the European cooperation in this field - based on Articles 126 and 127 of the Maastricht Treaty on the European Union signed in 1992 (149 and 150 in the Amsterdam Treaty of 1997) - is subject to the subsidiarity principle contained in Articles 3b and 5 respectively, i.e., support measures Art. 126 (general education): "The Community shall contribute to the development of quality education by encouraging cooperation between Member States and, if necessary, by supporting and supplementing their action" and Art. 127 (VET): "The Community shall implement a vocational training policy which shall support and supplement the action of the Member States" strictly limited to areas in which the Community's intervention is authorized explicitly and "only if and in so far as the objectives of the proposed action cannot be sufficiently achieved by the Member States and can therefore [...] be better achieved by the Community" (Art. 3b).

Hubert Ertl (2006) highlights that "both articles are similarly structured and extremely cautiously formulated" by reason of the principles of cultural autonomy (Art. 128) that emphasize the full respect of the "national and regional diversity", therefore leaving 


\section{J. Social Sci., 8 (2): 149-162, 2012}

full responsibility to the MS in relation to the organization of own educational systems and design of learning curricula (Spada, 2008).

The non-compulsoriness allows a variable flexibility with regard to the common objectives, calibrated on levels of trust/endorsement, or distrust/disaffection, of 'being in Europe'. And, regrettably, the elements of distrust and disaffection seem to be dominant in the present conjuncture. Not by chance, in the European Education Council of February 2009 , some of the founding members of the EU such as Germany and the Netherlands have joined the front of the 'Eurosceptics', expressing a clear opposition to the establishment of new indicators proposed by the European Commission in order to provide some added value by measuring the progress in specific arenas (mobility, occupation, languages, pre-primary education, investments in higher education). [...] The enthusiasm of Lisbon seems to run aground on the threshold of year 2010 and call into question even the prospects of revitalizing the co-operation Own translation.

The "conjuncture" Giunta La Spada refers to has, of course, much to do with the global economic turndown across the 2008-2009 period. It is understandable, in this light, that the EC's 'support measures', in the education field concentrate mainly on VET and mobility programmes, as free mobility of the European citizens and consequently of the European workers as means of production too, is one of the requisites for the European economic integration process, from the Single Market to the Economic Community, to a European Economic and Monetary Union. Moreover, "the pressures of the ongoing process of economic integration were used by the Commission to justify increasing financial incentives for the coordination of national policies in education and training" while, nonetheless, "the extended and more integrated EU activities still had limited impact on national systems" (Ertl, 2006).

The above views can be exemplified through the EU "financial incentives" and investments in AE. Most of EU funding for this sector comes to the European beneficiaries, as a return of the national contributions, from the European Social Fund (ESF) and especially from Grundtvig, the sectorial subprogramme for adult learners of the European Lifelong Learning Programme (which comprises the Erasmus, Comenius and Leonardo da Vinci subprogrammes, as well as the Study Visits, basically focusing on mobility of learners and staff). Having said that, is it not incongruous that Grundtvig still holds, in relation to the whole budget for the LLP 2007-2013, a negligible share of 4\% (EU, 2006a)? This of course tells a lot about the overall impact of this measure.
The adult learning sector is also strongly affected by an important heterogeneity: the provision of $\mathrm{AE}$ in the European MS covers a wide range of structures, priorities, learning contents, organizational forms, delivery methods, durations and learning outcomes. In particular, the opportunities for integrated learning trajectories are certainly affected by the strong decentralization and fragmentation of the competences and responsibilities in this domain at different levels: often several ministries involved (Ministry of Education, Ministry of Labor,), in-house or external governmental bodies, Regions/Länder, Provinces/Departments, municipalities, independent $\mathrm{AE}$ institutions and so on. On a regional level, for example, there is a strong involvement of employers and social partners, even though workplace and community learning still generally need to be promoted and reinforced with Rinne et al. (2007):

While the demand for traditional programmes of folk or liberal education was satured by comprehensive systems of primary and (lower) secondary education by the 1970s, the field became dominated by other forms of adult education-like vocational training, human resource development and academic (encyclopaedic) education. [...] Adult education has become more a component in the fragmented world of education than an independent form of education itself.

At the political tables within the EU comitology, next to the governmental delegates sit also a few representatives of the associations (e.g., EAEA, BusinessEurope), the unions (UEAPME) and the relevant agencies of the EU (CEDEFOP, ETF). Nevertheless, despite the strong effort the European Commission is undertaking in order to create a European framework for AE involving also the third sector and the corporations (responsible for the biggest share of the AE provision), the top-down approach is not very well describing what is happening in the reality. When a competence overlap engenders a responsibility deadlock, the institutional gap is normally filled at a lower level. In the adult learning sector, a number of actors have produced a large offer of AE provision, some of excellent quality, some other poorer. Through the different initiatives set up by the European Commission (working groups, peer-learning activities, transfer of innovation, guidelines and work programmes to achieve common goals, periodic monitoring,), that express the 'liturgy' of the Open Method of Coordination (OMC), this know-how, the good (or bad) practices are supposed to shift from the 


\section{J. Social Sci., 8 (2): 149-162, 2012}

ground to a higher level in order give the policy-makers knowledge, resources and tools to implement more systemic measures on a beneficiaries' needs basis (Maniscalco, 2010a).

This process could be successful, to some extent, because it is "largely depoliticised, with the OMC providing a managed consensus over the aims of the sector and the means of achieving them, as opposed to highly politicised national education debates" (Kallo et al., 2006). But the limits of the OMC as instrument chosen by the EU for the implementation of the Lisbon agenda derives from a paradox that Roger Dale explains in these terms (Dale and Robertson, 2009):

The complexities of the OMC expose the limitations of 'implementation' as a means of conceiving of the 'policy process', where a policy is devised by groups legitimated to do that and 'implemented' in a polity through the capacities of a governing body with legitimate authority and sovereignty. None of these features is found in the OMC and approaching it and seeing it as a form of implementation in this 'traditional' sense is somewhat misleading.

On the other hand, citizenship education (e.g., the "social and civic competences" included in the mentioned 2006 Recommendation on the Key Competences for Lifelong Learning) is perhaps the most politically sensitive and controversial part of the OMC in education due to its significant role in forging and maintaining the national identities (Naval et al., 2002; Keating et al., 2009). The fact that, especially in the last decade, supranational policies by the UNESCO, the Council of Europe and the EU in particular aim at dissociating citizenship from nationality (Soysal, 1994; Dale, 1999) is provoking in the European governments a certain caution in endorsing them, rightly because of the link existing between national sovereignty, citizenship and education and the fact that education used to lie under the indisputable control of the nationstates (Holmarsdottir and O'Dowd, 2009; Coulby and Zambeta, 2012).

\section{RESULTS AND DISCUSSION}

As shown, the skill development for adult learners in the EU education policies is meant to be influenced by the 2006 statement on the Key Competencies for lifelong learning as a red thread linking the general/compulsory education with the second chance and continuing education and training. This should impact, in the European perspective, the major arena which falls more strictly under the umbrella of the EU direct competence: the labor market supply and economic growth of the Union. Even in the EC surveys supporting the education policies it is not hard to find traces of such consequentiality (CASE, 2009):

\section{Identifying key competence development as a prime objective for schools links closely with the New Skills New Jobs agenda and therefore with strategies for using skills development to enable Europe to emerge successfully from the present economic crisis.}

Especially under the impulse of the OECD policy on adult learning (OECD, 1995; 2003; Roseveare, 1996 and OECD, 2006a Live longer, work longer statements, to mention a few) as well as the De.Se.Co. project and its 'practical' implementation tool, the PIAAC In the De.Se.Co project's final report, the editors suggest a model for levels of performance, based on approaches to reduce discrepancies between the competence (which "cannot be observed directly") and its outcomes by using real-life situations simulations (as in the PISAProgramme for International Student Assessment and in the ALL-Adult Literacy and Life Skills survey). At the same time, they warn on the "complex nature of competence", as it depends in large measure on the context. The PIAAC (Programme for the International Assessment of Adult Competencies), not surprisingly, takes into account merely basic/hard skills (literacy, numeracy, workplace and ICT skills), a much smaller set of competences to evaluate than the De.Se.Co. formulation. This is the result, again, of the political compromise on one side and, on the other side, of the difficulties in establishing objective parameters of evaluation whose outcomes, like the PISA tests, can be easily sold to the OECD Member States while using it for "soft policy" to influence them at the same time (Kallo and Rinne, 2006), the EU has invested substantially, in the last years, on the strengthening of the work skills too, but neglected an important dimension of the peoples' skills upgrading, which is strictly connected to the European active citizenship. From the APAL, aiming at increasing the participation of adult learners in all forms of lifelong learning (including non-formal, popular and liberal education), the EU AE policy evolution led to the Key Competences for Lifelong Learning (in line with the more 'humanistic' tradition of lifelong learning set by the UNESCO, 1970s (Faure, 1972) and finally to the New skills for the New jobs, which means-in practical terms-prioritizing the matching of the labor market's skill needs (CEDEFOP, 2008b; 2008c) in order to cope with its performativity and competitiveness. 


\section{J. Social Sci., 8 (2): 149-162, 2012}

As a matter of fact, the policy stream of the Adult Learning Action Plan, administered by the DG Education and Culture, does not link very well with the other EC policy stream of the New skills for New Jobs, launched by the DG Employment with the involvement of the ESF. While the first has an 'expost' approach to the problems correlated with the adult learning sector, from the validation of previous non-formal and informal learning undertaken by the workers to the improvement of the effectiveness of the MS' AE systems, the second has an 'ex-ante' approach, aiming at anticipating the future market's skill needs (CEDEFOP, 2009):

The European Commission in its
Communication of 26 November 2008 New
Skills for New Jobs: Better Matching and
Anticipating Labour Market Needs, which is
closely linked to the package of measures for
growth and jobs and which complements the
European Economic Recovery Plan, proposed
a series of actions to match skills with
vacancies, organise skills assessments on a
permanent basis, pool the efforts of Member
States and other international organisations
and develop better information on future
needs. The New Skills for New Jobs agenda
aims to improve monitoring of short-term
trends and to develop tools for better matching
of skills and job vacancies on the European
labour market, including better information on
needs in the EU in the medium and long term,
with regularly updated projections of future
labour market trends (done by CEDEFOP) and
analysis of skills needs by sector. Moreover, the
Commission will help Member States and
regions and all actors involved in upgrading and
matching skills by mobilising existing
Community policies and funds, especially the
European Social Fund.

Considered then a major "socioeconomic challenge", the skill mismatch in future labor markets is described by CEDEFOP as "both a complex and a pervasive problem in Europe", because "given the trends towards increasing skill requirements in all sectors and occupations, there are concerns about potential mismatches between labour force education and skill levels on the one hand and job requirements in the labour market on the other" (CEDEFOP, 2009). This is why, according to the EU agency, "more research on these issues can provide policy-makers with valuable insights into shaping and implementing innovative policies and measures aimed at preventing or addressing skill mismatch problems. CEDEFOP intends to update its forecasts every two years, starting in 2009" (ibid). The background for the involvement of CEDEFOP in the monitoring of the skill mismatch in Europe, started in the early 2000s (CEDEFOP, 2003; 2004), lays in the Conclusions on the New Skills for New Jobs-Anticipating and matching labour market and skills needs, 2930th Employment, Social Policy, Health and Consumer Affairs Council Meeting of 9 March 2009 in Brussels, where the Council of the EU established "a regular assessment of long-term supply and skills needs, by harnessing existing resources and, in particular, CEDEFOP, Eurofound and European Training Foundation".

Antonio Giunta La Spada noticed this turning point already in 2008 (Spada, 2008):

As occupation and work are vital, today as in the past, the issue of the common market is directly correlated with the principles of freedom of movement and relocation [of workers] and the auspices of common policy for Vocational Education and Training (VET). This is why-and the statement on the New Skills for New Jobs is a significant example-VET will advance much faster than the education sector, towards stronger forms of integration Own translation.

Referring to the EC's white paper Teaching and Learning: Towards the learning society of 1991, whose objective was "to help Europe move towards the knowledge-based society as a necessary step in economic and social progress", Merricks (2001) points out that, if the solution proposed was to strengthen and promote active citizenship and employability, the very limit was the "tension between the two elements" Tuckett (1997) and Watson and Taylor (1998) in terms of political consensus but also accountability:

The 'vocational' aspect could be justified in terms of pragmatic economic need, but notions of knowledge designed to create more democratic or informed society are rather more difficult to justify, especially since even ideas about 'citizenship' have historically embraced very different views. In practice, this problem was dealt with within the EU by concentrating on vocational training initiatives.

With Ertl's words, "the discourse on the concept of economic competitiveness has changed the formulation of new EU policies in education and training, exemplified by a strong emphasis on educational indicators, benchmarks and quality controls" (Ertl, 2006), that he labels as "intergovernmental extension of 
the foundations" (p. 14). According to him, "the postLisbon policy model builds on intergovernmental legal foundations that follow the rationale dictated by the concept of global economic competitiveness" (p. 20). Also Milana describes the EU policies on skills upgrading as a result of "the intersection between economic and education policy fields" and concludes that 'the EU 'regulatory ideal' for competence development is based on a simplified account of the social problem it aims to address" (Holmarsdottir and O'Dowd, 2009). She eventually interprets the EU policy discourse on the skills mismatch in the following way (ibid, 18-19):

Skilled workers and professionals are addressed as the only actors responsible for present mismatch between labour supply and demand, when the assumption is made that the supply of decent jobs in EU Member States is adequate, but the work force is unfortunately not adequately skilled to fill them. This assumption may discharge EU Governments from responsibility for direct intervention, aimed at creating new job opportunities and improving general working conditions for all.

\section{CONCLUSION}

The Lisbon 'catchphrase', urging the EU to become "the most dynamic, competitive knowledgebased economy in the world" by 2010 Conclusions of the Presidency of the European Council of the EU held in Lisbon, 23-24 March 2000 where education is conceived as "a key part of productive social policy" (Kallo et al., 2006) and societal participation is somehow subordinated to economic enhancement, should summarize the arguments discussed thus far, but actually entails more questions than it answers. In 2006, Roger Dale recognized that "the Lisbon Declaration boldly hailed 'Europe' as an economy, as an entity with the political-administrative capacity to achieve the targets, as being capable of and responsible for, organizing its MS to achieve the targets, as beneficiary or putative success of the strategy, as well as having a distinct educational mandate" (ibid, 30). But public policies aiming at fostering the participation of adults into lifelong learning (e.g., the 5th benchmark for the European performance, set in the framework of the Lisbon agenda) even raise questions of democratic freedom, in reason of the commitment of the EU governments in involving their citizens in learning paths where civic and social dimensions are neglected for reason of employment and economic growth concerns. Little consideration, for instance, seems to be given to the fact that the social sciences and cognitive neurosciences argue that the self-concept of adults itself changes during the lifespan, in transformations that imply smaller importance attributed to various life domains, the elaboration of possible selves and the strategies employed to preserve stability. As people age they tend to change the timing and methods of attaining a goal, they lower their expectations and they are more ready to abandon a far too ambitious goal. In a recent survey, Rinne and Jauhiainen reported that even in Finland, where the "respect for education and learning is high" (Rinne et al., 2007), "education received in middle age and especially after retirement is valued noticeably less than earlier schooling. Education during retirement was not really valued at all" (p. 116).

Of course, the global markets and the acceleration of technological change has made it quite likely that most persons will experience radical job and career diversification during their working lives and the paradigm of a European 'knowledge-based' economy in a background of a rapidly aging population is subject to determine the constant and urgent need for re-training the adults, at least until they exit the labor market (Santrock, 1985). And then? Adult learning is a sensitive reality that involves reflections of different amplitude in relation to the 'older adults' or the socalled 'later life'. In contrast with the views on the impact of ageing on a decline in work performance, the competing concept has nonetheless been "gaining currency in some quarters in Europe in recent years" (Nyhan, 2006). Thus, while older people may not have, for example, up-to-date information and communication technology skills, they do have valuable life experiences giving them important cognitive and personal competences and work-ethic virtues. This is why executives should "think about what they are losing in letting older workers leave their companies" (ibid.).

Other issues to consider are indeed the social and health care, the emerging role of the physical conditions of the individuals (which also impacts the adult learning cognitive development and learning ability), but also more 'philosophical' matters such as the retrospective appreciation of a life slowly approaching its end require reflection and examination, as the expression of the active ageing must be measured, as well, in terms of "replacing those relationships, activities and roles of middle age with new ones to maintain activities and life satisfaction" (Walker, 2002). Because including in the AE policy formulations that strike a good balance between the improvement of working skills, 
competences for an active participation in the society (Woodhead et al., 1988) and preparing the individuals to a smooth transition through the different stages of the human life would be, first of all, a proof of political responsibility.

\section{REFERENCES}

Adnett, N., 2001. Modernizing the European social model: Developing the guidelines. J. Common Market Stud., 39: 353-64. DOI: 10.1111/14685965.00292

Atkinson, R.D. and R.H. Court, 1998. The New Economy Index: Understanding America's Economic Transformation. 1st Edn., Progressive Policy Institute, Washington, pp: 198.

Autor, D.H., F. Levy and R.J. Murnane, 2003. The Skill content of recent technological change: An empirical exploration. Quarterly J. Econom., 118: 1279-333. DOI: 10.1162/003355303322552801

Baker, D.P. and G.K. LeTendre, 2005. National Differences, Global Similarities: World Culture and the Future of Schooling. 1st Edn., Stanford University Press, Stanford, ISBN-10: 0804750211 pp: 194.

Baron, A. and M. Armstrong, 2007. Human Capital Management: Achieving Added Value Through People. 1st Edn., Kogan Page, London, ISBN-10: 9780749451370 pp: 226.

Barro, R.J. and E.P. Lazear, 2002. Education in the Twenty-First Century. 1st Edn., Hoover Institution Press, Stanford, ISBN-10: 0817928928 pp: 192.

Barro, R.J., 1999. Determinants of Economic Growth: A Cross-Country Empirical Study. 2nd Edn., MIT Press, Cambridge, ISBN-10: 0262024217 pp: 145.

Barro, R.J., 2001. Human capital and growth. Am. Econ. Assoc., 91: 12-17.

Becker, G.S., 1964. Human Capital. A Theoretical and Empirical Analysis with Special Reference to Education. 1st Edn., National Bureau of Economic Research, Columbia, pp: 187.

Bell, D., 1973. The coming of post-industrial society. A venture in social forecasting, new york: Basic Books. Losing Winning, Psychology Today, 34: 48-51.

Brockmann, M., L. Clarke and C. Winch, 2008. Knowledge, skills, competence: European divergences in Vocational Education and Training (VET)-the english, german and dutch cases. Oxford Rev. Edu., 34: 547-67. DOI: 10.1080/03054980701782098

CASE, 2009. Key Competences in Europe: Opening doors for lifelong learners across the school curriculum and teacher education. CASE.
Castells, M., 1996. The information Age: Economy, Society and Culture. 1st Edn., Blackwell, Cambridge, ISBN-10: 1557866163 pp: 556.

CEDEFOP, 2003. Early identification of skill needs in Europe, Luxembourg. CEDEFOP.

CEDEFOP, 2004. Identifying skill needs for the future. CEDEFOP.

CEDEFOP, 2006a. Promoting lifelong learning for older workers, Luxembourg. CEDEFOP.

CEDEFOP, 2006b. Typology of knowledge, skills and competences: clarification of the concept and prototype. CEDEFOP.

CEDEFOP, 2008a. The shift to learning outcomes. CEDEFOP.

CEDEFOP, 2008b. Skill needs in Europe. CEDEFOP.

CEDEFOP, 2008c. Future skill needs in Europe. CEDEFOP.

CEDEFOP, 2009. Continuity, consolidation and change. CEDEFOP.

Coulby, D. and E. Zambeta, 2012. World Yearbook of Education 2005, . Globalization and Nationalism in Education. 1st Edn., Routledge, ISBN-10: 9780415501002

Dale, R. and S.L. Robertson, 2009. Globalisation and Europeanisation in Education. 1st Edn., Symposium Books, Oxford, ISBN-10: 1873927908 pp: 264.

Dale, R., 1999. Specifying globalization effects on national policy: A focus on the mechanisms. J. Edu. Policy, 14: 1-17. DOI: $10.1080 / 026809399286468$

Descy, P. and M. Tessaring, 2001. Training and Learning for Competence: Second Report on Vocational Training Research in Europe: Executive Summary. 1st Edn., Office for Official Publications of the European Communities, Luxembourg, ISBN-10: 9289600209 pp: 44.

Drucker, P.F., 2009. Post-Capitalist Society. 1st Edn., HarperCollins e-books, New York, ISBN-10: 9780061985966 pp: 240.

EC, 2004. european commission staff working paper SEC (2004) 73, Progress towards the common objectives in education and training. EC.

EC, 2005. European commission staff working paper SEC (2005)419, Progress towards the Lisbon objectives in education and training. EC.

EC, 2006. Communication from the commission COM (2006)614-final It is never too late to learn. EC.

EC, 2007a. Commission staff working document SEC (2007)1098 Towards more knowledge-based policy and practice in education and training. EC.

EC, 2007b. Communication from the commission COM (2007) 558-final It is always good time to learn. EC. 
EC, 2008a. Communication from the European commission COM (2008) 865-final on an updated strategic framework for European cooperation in education and training. EC.

EC, 2008b. Communication from the European commission COM (2008) 868-final on the New Skills for New Jobs. EC.

EC, 2008c. Commission staff working document SEC (2008) 3058 accompanying the communication from the European Commission COM (2008)868final on the New Skills for New Jobs. EC.

EC, 2010. A Decade of European Innovation in Adult Learning. European Commission.

Engle, A.D., M.E. Mendenhall, R.L. Powers and Y. Stedham, 2001. Conceptualizing the global competency cube: A transnational model of human resource. J. Eur. Ind. Train., 25: 346-353. DOI: 10.1108/EUM0000000005836

Ertl, H., 2006. European Union policies in education and training: The Lisbon agenda as a turning point?, Comparative Edu., 4: 5-27. DOI: 10.1080/03050060500515652

EU, 2000. Lisbon European council: Presidency conclusions. EU

EU, 2006a. Decision of European Parliament and of the Council of the EU 1720/2006/EC establishing an action programme in the field of lifelong learning, Brussels. EU.

EU, 2006b. Recommendation of the European parliament and of the council of the EU 2006/962/EC on the Key competences for lifelong learning, Brussels. EU.

EU, 2007. Resolution of the council of the EU 2007/C 290/01 on the New skills for new jobs, Brussels. EU.

EU, 2008. Conclusions of the council of the EU on adult learning. Official J. Eur. Union.

Eurydice, 2002. Key Competencies: A Developing Concept in General Compulsory Education. Ministerio de Educacion, Brussels, ISBN-10: 2871163464 pp: 180.

Faure, E., 1972. Learning to be: The World of Education Today and Tomorrow. 1st Edn., Paris, ISBN-10: 9231010174 pp: 313.

Franceschi, C., C. Caruso and G. Biolo, 2004. Le Basi Biologiche E Genetiche Dell'invecchiamento. 1st Edn., Forum Service, ISBN-10: 8886563884 pp: 106.

Gonczi, A., 1994. Developing a Competent Workforce: Adult Learning Strategies for Vocational Educators and Trainers. 1st Edn., National Cantre for Vocational Education Research, Leabrook, ISBN10: 0863972624 pp: 306.

Gustafsson, B., 2002. What do we mean by lifelong learning and knowledge? Int. J. lifelong Edu., 21: 13-23. DOI: 10.1080/02601370110099489
Hager, P., 1994. Is there a cogent philosophical argument against competency standards. Australian J. Educ., 38: 3-18.

Hake, B.J., 1999. Lifelong learning in late modernity: the challenges to society, organizations and individuals. Adult Edu. Quarterly, Sage, 49: 79-90. DOI: $10.1177 / 074171369904900201$

Holmarsdottir, H.B. and M. O’Dowd, 2009. Nordic voices: Teaching and Researching Comparative and International Education in the Nordic Countries. 1st Edn., Sense Publishers, Rotterdam, ISBN-10: 9087909721 pp: 317.

Kallo, J. and R. Rinne, 2006. Supranational Regimes and National Education Policies: Encountering Challenge. 1st Edn., Finnish Educational Research Association, Helsinki, ISBN-10: 9525401235, pp: 377.

Kallo, J., R. Rinne and S.K. Seura, 2006. Supranational Regimes and National Education Policies: Encountering Challenge. 1st Edn., Finnish Educational Research Association, Helsinki, ISBN: 9525401235 pp: 377.

Kamens, D.H. and C.L. McNeely, 2010. Globalization and the growth of international educational testing and national assessment. Comparative Edu. Rev., 54: 5-25. DOI: 10.1086/648471

Katz, R.L., 1955. Skills of an effective administrator. Harvard Bus. Rev., 33: 33-42.

Keating, A., D.H. Ortloff and S. Philippou, 2009. Citizenship education curricula: the changes and challenges presented by global and European integration. J. Curriculum Stud., 41: 145-58. DOI: 10.1080/00220270802485063

Lipsey, R.G. and K. Lancaster, 1956. The general theory of second best. Rev. Econ. Stud., 24: 11-32.

Lorenz, K., 1973. Die acht Todsünden Der Zivilisierten Menschheit. 1st Edn., Piper, Munchenpp, ISBN10: 3492003508 pp: 112.

LSE, 2006. Boosting innovation and productivity growth in Europe: The hope and the realities of the EU's Lisbon agenda The London School of Economics and Political Science, Centre for Economic Performance.

Maniscalco, R.S., 2008. La competenza interlinguistica e interculturale per la cittadinanza globale, I quaderni del Lifelong Learn. Programme, 5: 9-13.

Maniscalco, R.S., 2010a. The Impact of the European policies on the new skills for the new jobs. Rev. Eur. Stud., 2: 54-66.

Maniscalco, R.S., 2010b. Italia: Un Paese che invecchia. Prospettive di formazione permanente e istruzione nell'eta adulta. Settentrione, 22: 85-92.

Mazza, S. and G. Capacci, 2006. L'invecchiamento della popolazione italiana: Effetti e politica sociale. Quaderni Eur. Welfare, Milan: Macros Res., 5: 51-68. 
Merricks, L., 2001. The age of Learning: Education and the Knowledge Society. 1st Edn., Routledge, ISBN-10 0749434120 pp: 230.

Mulder, M., T. Weigel and K. Collins, 2007. The concept of competence in the development of vocational education and training in selected eu member states: A critical analysis. J. Vocational Edu. Train., 59: 67-88. DOI: 10.1080/13636820601145630

Murnane, R.J. and F. Levy, 1996. Teaching the New Basic Skills: Principles for Educating Children to Thrive in a Changing Economy. 1st Edn., Free Press, New York, ISBN-10: 0684827395 pp: 250.

Naval, C., M. Print and R. Veldhuis, 2002. Education for democratic citizenship in the new europe: Context and reform. Eur. J. Edu., 37: 107-128. DOI: 10.1111/1467-3435.00097

Nyhan, B., 2006. New Policy Thinking on the Relationship berween Age, Work and Learning. In: Promoting Lifelong Learning for Older Workers: An International Overview, Tikkanen, T. and B. Nyhan, (Eds.). Office for Official Publications of the European Communities, pp: 18-47.

OECD, 1995. The labour market and older workers, social policy studies. OECD.

OECD, 2003. Beyond rhetoric: Adult learning policies and practices-highlights. OECD.

OECD, 2005. The definition and selection of key competences. OECD.

OECD, 2006a. Live longer, work longer. OECD.

OECD, 2006b. Education at a Glance. OECD.

O'Sullivan, A. and S.M. Sheffrin, 2007. Economics, Principles in Action. 1st Edn., Pearson/Prentice Hall, Boston, ISBN: 0131334840 pp: 592.

Peterson, T.O. and D.D.V. Fleet, 2004. The ongoing legacy of R.L. Katz: An updated typology of management skills. Manage. Decision, 42: 1297308. DOI: 10.1108/00251740410568980

Rinne, R., A. Heikkinen and P. Salo, 2007. Adult Education - Liberty, Fraternity Equality?: Nordic views on lifelong learning. 1st Edn., Finnish Educational Research Association, Helsinki, ISBN10: 9789525401288 pp: 415.

Roseveare, D., 1996. Ageing Populations, Pension Systems and Government Budgets: Simulations for 20 OECD Countries. 1st Edn., OECD Economics Department Working Paper, Paris, pp: 69.
Santrock, J.W., 1985. Adult Development and Aging. 1st Edn., Brown, Dubuque, ISBN-10: 0697000850 pp: 538.

Savvides, A. and T. Stengos, 2009. Human Capital and Economic Growth. 1st Edn., Stanford Economics and Finance, Stanford, ISBN-10: 9780804755405 pp: 240.

Schultz, T.W., 1961. Investment in Human Capital. Am. Econ. Rev., 51: 1-17.

Sekerak, J. and D. Sveda, 2008. Is Mathematics teaching developing learner's key competences, Teaching Math., 11: 41-52.

Sloan, K., 2006. Teacher identity and agency in school worlds: Beyond the all-good/all-bad discourse on accountability-explicit curriculum policies. Curriculum Inquiry, 36: 119-152. DOI: 10.1111/j.1467-873X.2006.00350.x

Soysal, Y.N., 1994. Limits of Citizenship: Migrants and Postnational Membership in Europe. 1st Edn., The University of Chicago Press, Chicago, ISBN-10: 0226768414 pp: 224.

Spada, G.L.A., 2008. Istruzione e formazione: Quali prospettive per la cooperazione europea. Annali della Pubblica Istruzione, 3: 5-10.

Stehr, N., 1994. Knowledge Societies. 1st Edn., Sage, London, ISBN-10: 080397891X pp: 291.

Tovey, L., 1993. A strategic approach to competency assessment. J. Eur. Indu. Train.

Tuckett, A., 1997. Lifelong Learning in England and Wales: An Overview and Guide to Issues Arising From the European Year of Lifelong Learning. 1st Edn., National Institute of Adult Continuing Education, Leicester, ISBN-10: 1862010129, pp: 34.

Walker, A., 2002. A strategy for active ageing. Int. Soc. Secu. Rev., 55: 121-139. DOI: 10.1111/1468246X.00118

Watson, D. and R. Taylor, 1998. Lifelong Learning and the University: A Post-Dearing Agenda. 1st Edn., Routledge, ISBN-10: 0750707844 pp: 178.

Woodhead, A.D., M.A. Bender and R.C. Leonard, 1988. Phenotypic Variation in Populations: Relevance to Risk Assessment. 1st Edn., Plenum Press, New York, ISBN-10: 030642794X, pp: 305. 